\title{
Growth and production of nasturtium flowers in three hydroponic solutions
}

\author{
Evanisa Fátima RQ Melo ${ }^{2 *}$; Osmar S dos Santos ${ }^{3}$ \\ ${ }^{2}$ UPF, BR 285, São José, 99052-900 Passo Fundo-RS; evanisa@upf.br; evanisa9@gmail.com; ${ }^{3}$ UFSM, Colégio Politécnico, Av. Roraima, \\ 1000, Camobi, 97105-900 Santa Maria-RS; *Autor correspondente
}

\begin{abstract}
This experiment was carried out during April to August 2003 in a greenhouse at the Universidade Federal de Santa Maria, Rio Grande do Sul state, Brazil. The growth and production of nasturtium flowers (Tropaeolum majus) in hydroponics NFT system was typified. Treatments were displayed in a $3 \times 11$ factorial, with six replications, in entirely randomized experimental design, and were composed of three nutrition solutions and 11 assessment dates. Each plant was separated between aerial part and root for the evaluation of dry mass. The blossoming started 49 days after the transplant (DAT). The plants presented good development in hydroponics, as well as growing dry mass, stature, leaf area and IAF, during the cycle. The culture's growth rate presented larger accumulation of leaf mass from 49 DAT on, in linear relation. Biological productivity was adjusted to a $2^{\text {nd }}$ degree equation. Nutrition solutions did not show statistical differences, however, Furlani (1997) solution was the most reasonably priced.
\end{abstract}

Keywords: Tropaeolum majus, capuchinha, edible flowers, yield.

\section{RESUMO}

Crescimento e produção de flores de nastúrcio cultivado em hidroponia com três soluções nutritivas

Com o objetivo de caracterizar o crescimento e produção de flores de nastúrcio (Tropaeolum majus) em hidroponia, no sistema NFT, conduziu-se um experimento em casa de vegetação da Universidade Federal de Santa Maria, de abril a agosto de 2003. O experimento foi um fatorial 3x11 com seis repetições, em delineamento experimental inteiramente casualizado, sendo os tratamentos constituídos de três soluções nutritivas e 11 datas de avaliação. Dividiu-se cada planta em parte aérea e raiz para avaliação da fitomassa seca. A floração iniciou aos 49 dias após o transplante (DAT). A planta apresentou bom desenvolvimento em hidroponia sendo a produção de fitomassa seca crescente durante o ciclo, bem como a estatura, a área foliar e o IAF. A taxa de crescimento da cultura apresentou maior acúmulo de fitomassa a partir dos 49 DAT com relação linear. A produtividade biológica ajustou-se a uma equação do $2^{\circ}$ grau. As soluções nutritivas não apresentaram diferença estatística entre si, porém na análise de custo a solução Furlani (1997) foi a mais econômica.

Palavras-chave: Tropaeolum majus, capuchinha, flores comestíveis, produtividade.

(Recebido para publicação em 30 de setembro de 2010; aceito em 10 de outubro de 2011) (Received on September 30, 2010; accepted on October 10, 2011)

The nasturtium (Tropaeolum majus) also known as nasturtium, capuchinha, mastruço, chagas or Mexican watercress, has as diversity centers Brazil, Peru, Colombia and south from Mexico to Patagonia (Comba et al., 1999; Joly, 2002). It belongs to the Tropaeolaceae family and is an annual herbaceous climber, with a circular stem, alternate green hairy, whole leaves and big, pretty flowers ranging from yellow to red in color (Martins et al., 1994; Joly, 2002; Lorenzi \& Souza, 2008).

The medicinal properties of the nasturtium have triggered interest in the food and phytochemical area. The increase in the number of edible flowers in recipe books, culinary magazine articles and television advertisements shows that they are becoming more popular (Rusnak, 1999).
Large supermarkets, grocery stores and stores specialized in culinary products commercialize edible flowers which are used in salads, canapés and conserves, in both sweet and savory dishes, using the delicious petals in salads and other dishes for decoration and because their flavor is greatly appreciated.

Nasturtium flowers are extremely tasty, with a sharp flavor due to some sulfur compounds and can be used in food, medicine and landscape gardening, because there are bred varieties adapted to different environments with brightly colored flowers (Lorenzi \& Souza, 2008). But there are few studies in Brazil on the agronomic aspects of this plant, even though it is an excellent cropping alternative for small producers (Melo, 2006). Studies were found on the relationship between spacing and nasturtium growth (Ferreira, 2000; Ramos et al., 2003; Sangalli et al., 2004; Lopes et al., 2007) that reported that between plot spacing was associated to crop yield and influenced flower production and leaf area. However, experiments were carried out in hydroponia using the nutritive solution described by Hoagland \& Arnon (1950), and it was observed that the dry and green matter production increased during the cycle and the leaf matter compared with the canopy matter (stem and petioles) represented $25.7 \%$ of the total matter, with significant correlation for leaf green matter and the canopy of $96.95 \%$ and for dry leaf matter in relation to the canopy it was $96.54 \%$, and the leaves are an important component of the plant mass (Melo \& Santos, 2006).

${ }^{1}$ Parte da tese de doutorado da primeira autora. 
Flowers can be produced in hydroponia in the Nutrient Film Technique (NFT) system or with different substrates such as expanded clay, sand and mineral wool but the NFT system is the most economic and easiest to use (Martinez \& Barbosa, 1996). Cropping in hydroponia results in products with excellent quality, flavor and superior external aspects to those obtained in traditional agriculture and there is less risk of contamination by endemic diseases. The nutritive solution and cropping conditions should be adjusted to the nutritional requirements of each plant species, cultivar, growing environment, period of the year (light intensity and temperature) and quality of the water used in the hydroponic cropping. The nutritive solution composition should consider the total nutrient supply and the proportion of the various nutrient elements, that is directly related to the solution volume available per plant, plant development stage, absorption rates and nutritional replacement frequency or solution renovation (Teixeira, 1996; Martinez, 1997; Furlani et al., 1999; Santos, 2010).

Plants have great capacity to adapt to different nutritive solutions because nutrient absorption is selective. However, the limits should be considered of $\mathrm{pH}$, osmotic pressure and proportion among nutrients, so that one does not interfere in the absorption of the other and no insoluble compounds are precipitated, and balance is needed among the nutrients (Hoagland \& Arnon, 1950).

There are many nutritive solution formulations recommended for various plant species, but there are no references for nasturtium cropping. The best solution should be determined because there are great differences in nutrient concentration.

The objective of the present study was to characterize the growth and edible flower production of the nasturtium (Tropaeolum majus) in hydroponics with three nutritive solutions.

\section{MATERIAL AND METHODS}

The experiment was carried out in a greenhouse with a plastic roof at the Federal University of Santa Maria (29\%41'25'S, 5348'42'”, 95 $\mathrm{m}$ altitude), installed in the north-south direction. The climate according to the Köeppen classification is the $\mathrm{Cfa}$, humid subtropical, with rains well distributed throughout the year and subtropical temperatures. The mean annual temperature is approximately $19.3^{\circ} \mathrm{C}$ and the mean relative air humidity is $78.4 \%$. July is considered the coldest month, with a mean minimum temperature of $9.3^{\circ} \mathrm{C}$ and January the warmest month, with $31.8^{\circ} \mathrm{C}$ mean maximum temperature.

The nasturtium cultivar Jewel Mix was sown on April 29, 2003 on 128-well extruded polystyrene trays filled with organic-mineral Plantmax ${ }^{\circledR}$ substrate with one seed per well. The plantlets were placed in a nursery with nutritive solution recommended for lettuce (Castellane \& Araújo, 1995) diluted to $25 \%$ and irrigated twice a day. The nutritive solution $\mathrm{pH}$ was corrected every two days and kept between 5.8 and 6.2. The $\mathrm{pH}$ was adjusted with sodium hydroxide $(\mathrm{NaOH} 0.3 \mathrm{~N})$ or sulfuric acid $\left(\mathrm{H}_{2} \mathrm{SO}_{4} 10 \%\right)$ whenever necessary. The nutritive solution temperature was around $25^{\circ} \mathrm{C}$ (Santos, 2010) so as not to interfere in root development and nutrient absorption.

The plantlets were transplanted to the definite benches when they were 10 cm tall, 21 days after sowing and were assessed every seven days, in a 98-day cycle. Each bench consisted of four channels (polypropylene tubes) $6 \mathrm{~m}$ long and $5 \mathrm{~cm}$ deep, with $5 \mathrm{~cm}$ diameter holes spaced every $25 \mathrm{~cm}$ in the channels and $40 \mathrm{~cm}$ between channels.

Table 1 shows the nutritive solutions. They were stored in $500 \mathrm{~L}$ fiberglass reservoirs, attached to a $0.5 \mathrm{HP}$ motor pump set that supplied nutritive solution at $2.0 \mathrm{~L} \mathrm{~min}^{-1}$. The circulation time of the nutritive solution was controlled by a temporizer that started the set for 15 minutes with 15 minute intervals from 6 a.m. to 6 p.m. and for 15 minutes every four hours at night.

Acomplete randomized experimental design was used with a $3 \times 11$ bifactorial design with six replications (three plants per replication), three nutritive solutions recommended by Hoagland \& Arnon
(1950), Castellane \& Araújo (1995) and Furlani (1997), and 11 assessment periods: $7,14,21,28,35,42,49,56,63$, 70 and 77 days after transplant (DAT).

Phenometric measurements were taken every seven days, when six plants were collected per treatment. To determine the height of the canopy, a millimeter ruler was used to measure from the base of the stem to the tip of the plant. The leaf area was determined by the disk method that consisted of removing 20 discs from random leaves using a puncher with $2.01 \mathrm{~cm}^{2}$ area. The leaf area was determined by the rule of three: $A F=A D \times F S F \times N D / F S D$, where: AD was the disk area $\left(\mathrm{cm}^{2}\right)$, FSF the dried leaf plant matter (g), ND the number of disks and FSD the disk dry plant matter $(\mathrm{g})$. The leaf area index (LAI) was obtained by the ratio of the leaf area (LA) in $\mathrm{cm}^{2}$ with the area occupied by one plant $\left(1000 \mathrm{~cm}^{2}\right)$. The number of flowers was determined by counting. The plants were separated into the canopy and root that were placed in individual paper bags and taken to a drying chamber with forced air ventilation at $65^{\circ} \mathrm{C}$ until constant matter was obtained to determine the dry plant matter. The crop growth rate (CGR) and biological productivity (BP) were determined according to the methodology by Magalhães (1985) and Benincasa ( 1988).

The values obtained were submitted to analysis of variance and regression analysis. When selecting the polynomial regression equations, the significance of the effect of the models was tested by the $F$ test at $5 \%$ probability of error.

The cost of each nutritive solution was calculated based on the current retail price of the nutrients in Santa Maria.

\section{RESULTS AND DISCUSSION}

There was no significant interaction among the nutritive solutions and the assessment dates for the variables studied. Growth in canopy height was slow until 28 days after transplant (DAT), rates increased until the end of the period assessed and a maximum value of $180 \mathrm{~cm}$ was obtained at 77 DAT (Figure 1A). In research with 
Table 1. Chemical composition (g/1000 L) of three nutrient solutions used in nasturtium hydroponic cultivation (composição química (g/1000 L) das três soluções nutritivas utilizadas no cultivo de nastúrcio). Santa Maria. UFSM. 2003.

\begin{tabular}{lccc}
\hline Nutrients & $\begin{array}{c}\text { Hoagland \& Arnon } \\
(\mathbf{1 9 5 0 )}\end{array}$ & $\begin{array}{c}\text { Castellane \& Araújo } \\
\text { (1995) }\end{array}$ & $\begin{array}{c}\text { Furlani } \\
\text { (1995) }\end{array}$ \\
\hline Special calcium nitrate. $\mathrm{Ca}\left(\mathrm{NO}_{3}\right)_{2}$ & 1,181 & 950 & 1,000 \\
Potassium nitrate. $\mathrm{KNO}_{3}$ & 506 & 900 & 600 \\
Monoammonium phosphate. $\mathrm{NH}_{4} \mathrm{H}_{2} \mathrm{PO}_{4}$ & -- & --- & 150 \\
Monobasic potassium phosphate. $\mathrm{KH}_{2} \mathrm{PO}_{4}$ & 136 & 272 & --- \\
White potassium chloride. $\mathrm{KCl}_{\text {Magnesium sulphate. } \mathrm{MgSO}_{4} \cdot 7 \mathrm{H}_{2} \mathrm{O}}$ & --- & --- & 150 \\
Manganese sulphate. $\mathrm{MnSO}_{4} \cdot \mathrm{H}_{2} \mathrm{O}$ & 493 & 246 & 250 \\
Zinc sulphate. $\mathrm{ZnSO}_{4} \cdot 7 \mathrm{H}_{2} \mathrm{O}$ & 1.880 & 1.700 & 1.000 \\
Copper sulphate. $\mathrm{CuSO} \mathrm{S}_{4} \cdot 5 \mathrm{H}_{2} \mathrm{O}$ & 0.200 & 1.150 & 0.440 \\
Boric acid. $\mathrm{H}_{3} \mathrm{BO}_{3}$ & 0.060 & 0.190 & 0.100 \\
Sodium molibdate. $\mathrm{Na}_{2} \mathrm{MoO}_{4}$ & 2.860 & 2.850 & 1.020 \\
Iron sulphate. $\mathrm{FeSO}_{4}{ }^{*}$ & 0.135 & 0.120 & 0.130 \\
Na-EDTA* & 24.999 & 24.100 & 12.500 \\
\hline
\end{tabular}

Table 2. Balance of costs of nutrient solutions used in nasturtium hydroponic cultivation for one volume of $1000 \mathrm{~L}$ (comparação de custos das soluções nutritivas utilizadas no cultivo hidropônico de nastúrcio para um volume de 1000 L*). UFSM, Santa Maria, RS.

\begin{tabular}{lccc}
\hline Factors & $\begin{array}{c}\text { Hoagland \& Arnon } \\
(\mathbf{1 9 5 0 )}\end{array}$ & $\begin{array}{c}\text { Castellane \& Araújo } \\
(\mathbf{1 9 9 5 )}\end{array}$ & $\begin{array}{c}\text { Furlani } \\
(\mathbf{1 9 9 7})\end{array}$ \\
\hline Macronutrients (R\$) & 5.93 & 8.08 & 5.58 \\
Micronutrients (R\$) & 2.37 & 2.28 & 1.20 \\
Summ (R\$) & 8.30 & 10.36 & 6.78 \\
\% compared to the most expensive solution & 80.10 & 100.00 & 65.40 \\
\% compared to the less expensive solution & 122.90 & 152.80 & 100.00 \\
\hline
\end{tabular}

*Prices in Santa Maria, at June 29, 2006 (preços no mercado de Santa Maria, em 29 de junho de 2006); US\$1.00= R\$ 2,21.

nasturtium cropping, Castellani (1997) and Ferreira (2000) reported similar results to those of the present study for the canopy height variable in function of populations and flower arrangement and observed decreasing growth rates starting at 75 DAT. However, the flower yield of the nasturtium plant was directly related to the plant height and the quantity of green and dry matter in the plant canopy (Sangalli et al., 2004). Effect was also observed for phosphate fertilizer on the plant height and dry matter of the nasturtium canopy (Cessa et al., 2009).

The leaf area growth curve (Figure 1B) was polynomial quadratic from 14 to 77 DAT, with a minimum value at seven days after transplant, indicating that the plant started growth with an increase in leaf area up to the maximum point, observed in the last assessment. The results were in line with Ferreira (2000) who analyzed nasturtium growth characteristics in the Jewel cultivar, combining spacings and found greater leaf area $\left(15,000 \mathrm{~cm}^{2}\right)$ for plants cultivated in $0.3 \mathrm{~m}$ between-plant spacing, with maximum leaf area at 105 DAT. Lopes et al. (2007) worked with a density of $(60 \times 50 \mathrm{~cm})$ and found a greater leaf area per plant than at the highest density $(30 \times 25 \mathrm{~cm})$. The smaller leaf area found at the highest density can be explained by the greater competition among plants for light, water and nutrients. The maximum leaf area occurred at 47 and 42 days after transplant (DAT) for the $60 \times 50 \mathrm{~cm}$ and $30 \times 25 \mathrm{~cm}$ densities, respectively.

The leaf area index (LAI) increased exponentially from 42 to 77 DAT (Figure 1C). Optimum LAI permits the maximum photosynthesis, thus as the leaf area increases, the LAI also increases, and there is a directly proportional relationship until the value is reached where self-shading (number of leaves in the canopy with precarious illumination) decreases the photosynthesis efficiency of the plant (Benincasa, 1988). Similar results were reported by Ferreira (2000). This is the main productivity determining factor for a crop, due to the increase during growth and reaches the optimum value when the crop CGR is maximum (Magalhães, 1985).

Flower production started at 49 DAT and presented linear performance during the period assessed. Maximum flower production was obtained at 77 DAT, with a mean of 4.7 flowers per plant (Figure 1D). The nasturtium cropping temperature was a factor of great importance, when too high it caused flower abortion and early flowering. Excessive heating made oxygen less available in the nutritive 

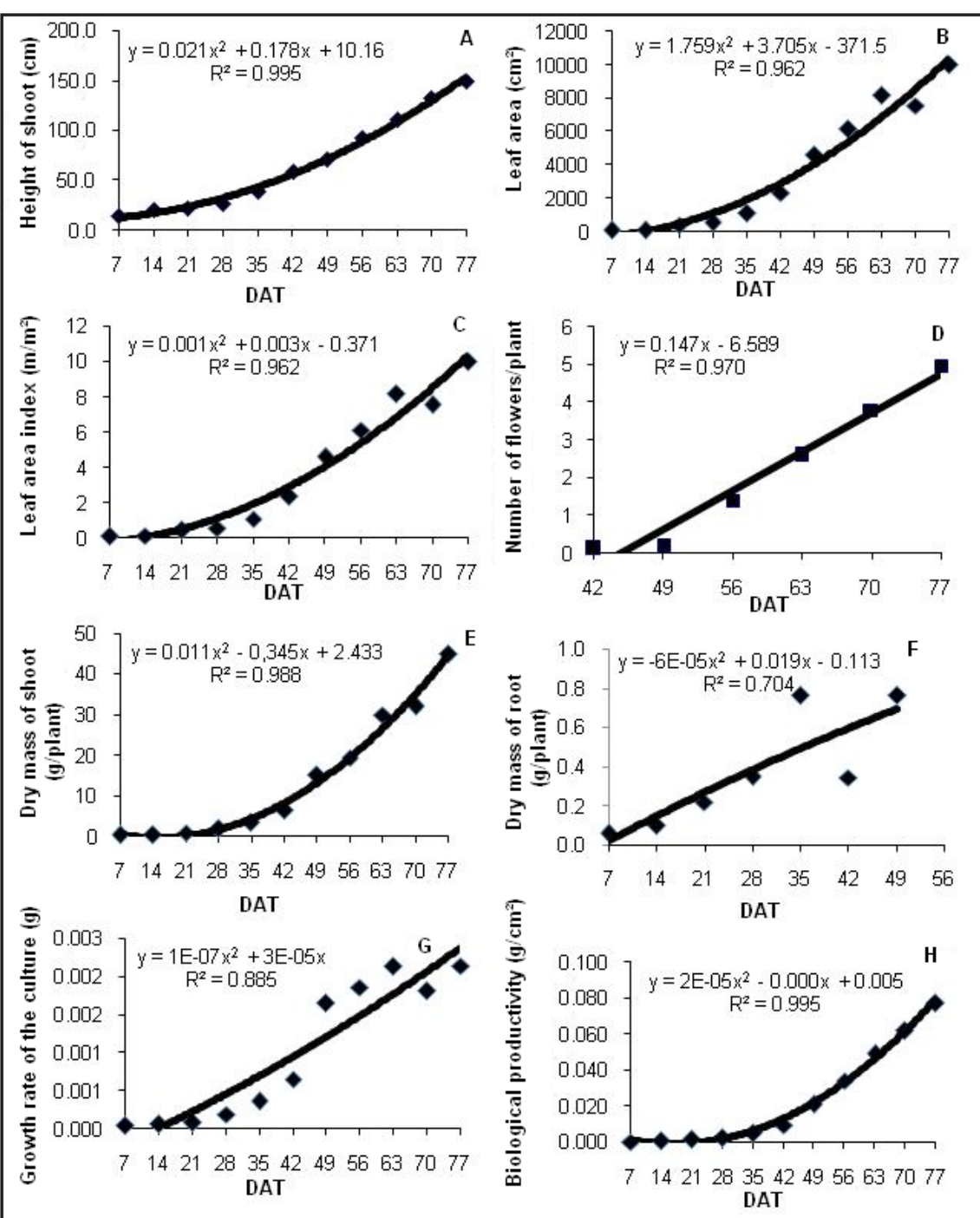

Figure 1. Height of shoot (A), leaf area (B), leaf area index (C), number of flowers (D), dry mass of shoot $(E)$, dry mass of root $(F)$, growth rate of the culture $(G)$ and biological productivity $(\mathrm{H})$ from nasturtium plants in hydroponics with three nutrient solutions (estatura da parte aérea (A), área foliar (B), índice de área foliar (C), número de flores (D), massa seca de parte aérea $(E)$, massa seca de raiz $(F)$, taxa de crescimento da cultura $(G)$ e produtividade biológica $(\mathrm{H})$ de plantas de nastúrcio em cultivo hidropônico com três soluções nutritivas). UFSM, Santa Maria, RS.

solution, decreases root respiration and consequently nutrient absorption, in line with Castellani (1997), Larcher (2000) and Santos (2010). Castellani (1997) stated that flower formation was induced within certain temperature limits. According to Larcher (2000) environmental factors influenced flowering frequency together with endogenous regulation, mainly by the effect of the nutritional state, and energy and nutrients necessary for flowering result from the photosynthesis activity, incorporating mineral substances, mobilizing reserve materials and assessed were in line with those in the literature, for example the studies carried out by Ferreira (2000), Larcher (2000), Ramos et al. (2003), Sangalli et al. (2004) and Cessa et al. (2009).

The root plant matter was not analyzed until the end of the cycle because the plant roots were tangled, that prevented their removal, but this was shown to be sufficient to maintain adequately the nutritive solution retention and water supply. The data obtained until 49 DAT fitted a linear equation (Figure 1F).

The crop growth rates (CGR) increased exponentially after 49 to 77 DAT (Figure 1G) and the plant means correlated well with the values estimated by the equation, with a determination coefficient of $88.5 \%$, indicating the constant growth of the plants.

The biological productivity (BP) showed greater dry plant matter accumulation after 49 DAT that increased until 77 DAT (Figure 1H) and a second-degree equation was obtained with a 0.99 determination coefficient $\left(\mathrm{r}^{2}\right)$ $(\mathrm{p}<0.05)$, that was in line with results reported by Ferreira (2000), Ramos et al. (2003), Sangalli et al. (2004) and Reis et al. (2006) who worked with different spacings and fertilizers.

The nasturtium plant growth was good as shown by the canopy dry plant matter production, but flower production was poor, probably harmed by the temperatures of around $30^{\circ} \mathrm{C}$ during the experimental period (Melo, 2006; Lopes et al., 2007). Environmental factors affect dry matter production because of their influence on the carbon dioxide gaseous exchange and carbon balance. Dry matter production increases under good radiation conditions (high intensity and long days) and optimum temperature, but low availability of these factors, water shortage and insufficient mineral nutrition or unbalanced nutrition can decrease the biomass yield (Larcher, 2000).

Thus, environmental temperature inside the greenhouse is a very important factor, because high temperatures cause, among other disturbances, flower abortion and early flowering. Furthermore, excessive heating makes oxygen less available in the nutritive 
solution, decreasing root respiration and thus nutrient absorption. Therefore the nutritive solution temperature should be around $25^{\circ} \mathrm{C}$ (Santos, 2010) so as not to harm root development, nutrient absorption and consequently the plant quality. Reaction to temperature depends on the plant species cropped, and in the research carried out on nasturtium it was observed that the plant does not tolerate temperature extremes whether low (less than $6^{\circ} \mathrm{C}$ ) or high $\left(\right.$ over $\left.33^{\circ} \mathrm{C}\right)$. This was in line with Moraes et al. (2004) who reported that on very sunny days the leaves and flowers became whitened, showing the effect of photo oxidation and that in Brazil this species should be cropped in cool climate period. The spacing used was not ideal because the plant growth was very vigorous in the three nutritive solutions causing shading that hindered sampling and prevented removal of a representative sample after 84 DAT, that is, when the plant was 105 days old, because it was tangled with the adjacent plants.

In hydroponics all the nutrients are supplied to the plant in the form of solution, prepared with fertilizers, but there are several salts that supply the same nutrients so that easily dissolved, cheap salts easily found on the market should be chosen. It is still not known how nasturtium growth and development take place in hydroponics; so it was chosen to test three nutritive solutions used for lettuce and later to determine a specific nutritive solution for the crop. The nutritive solution used did not present significant statistic difference in production that indicated that they were all capable of supplying the nutritional needs.

The lettuce crop yield was assessed in function of nutrient sources, in hydroponic cropping, and it was concluded that there was little influence from the nutritive solution (Fernandes et al., 2002). In hydroponic cropping of lettuce with six nutritive solutions, it was concluded that the solution suggested by Castellane \& Araújo (1995) presented superior production to the others and the best qualitative aspect (Santos, 2010).

The cheapest nutritive solution should be chosen in hydroponic cropping.
Thus the costs were analyzed to define which was the most economic (Table 2) to help select the nutritive solution. Taking as reference the most expensive solution, Castellane \& Araújo (1995) and comparing it with the Hoagland \& Arnon (1950) and Furlani (1997) solutions, the costs of these decreased to $80.1 \%$ and $65.4 \%$, respectively, and were more economic. In another interpretation, taking as reference the cheapest solution, Furlani (1997), reported that Castellane \& Araújo (1995) was 52.8\% more expensive and the Hoagland \& Arnon (1950) solution $22.4 \%$ more expensive. These results were in line with data obtained by Santos et al. (2004) where the three solutions studied did not differ for watercress yield, but were different for their respective costs.

Nasturtium flower production started 49 days after transplant (DAT) and the leaf area index, crop growth rate and biological productivity demonstrated greater plant matter accumulation after 49 DAT. The three nutritive solutions used did not present significant differences in nasturtium production, but the Furlani (1997) solution was the cheapest.

\section{REFERENCES}

BENINCASA MMP. 1988. Análise de crescimento de plantas (noções básicas). Jaboticabal: UNESP-FCAV. 41p.

CASTELLANE PD; ARAÚJO JAC. 1995. Cultivo sem solo - hidroponia. $2^{\mathrm{a}}$ ed. Jaboticabal: FUNESP. 43p.

CASTELLANI DC. 1997. Crescimento, anatomia e produção de ácido erúcico em Tropaeolum majus L. Viçosa: UFV. 180p (Dissertação mestrado).

CESSA RMA; MOTA JH; MELO EP. 2009. Produção de capuchinha cultivada em vaso com diferentes doses de fósforo e potássio em casa de vegetação. Gl. Sci. Technol. 2: 01-07.

COMBA L; CORBET SA; BARROM A; BIRD A; COLLINE S; MIYAZAKI N; POWELL M. 1999. Garden flowers: insects visit and the floral reward horticulturally: modified variants. Annals of Botany Company, London, 83: 73-86.

FERNANDES AA; MARTINEZ HEP; PEREIRA PRG; FONSECA MCM. 2002. Produtividade, acúmulo de nitrato e estado nutricional de cultivares de alface, em hidroponia, em função de fontes de nutrientes. Horticultura Brasileira 20: 195-200.

FERREIRA RBG. 2000. Crescimento, desenvolvimento e produção de flores $e$ frutos da capuchinha 'Jewel' em função de populações e de arranjos de plantas. Dourados: UFMS. 34p (Dissertação mestrado).

FURLANI PR. 1997. Instruções para o cultivo de hortaliças de folhas pela técnica de hidroponia NFT. Campinas: IAC. 30p (Boletim Técnico 168).

FURLANI PR; BOLONHEZI D; SILVEIRA LCP; FAQUIN V. 1999. Nutrição mineral de hortaliças: preparo e manejo de soluções nutritivas. Informe Agropecuário 20: 90-98.

HOAGLAND DR; ARNON DL. 1950. The water culture methods for growing plants without soil. Berkeley: University of California. 32p (Circular 347).

JOLY AB. 2002. Botânica - Introdução à taxonomia vegetal. $13^{\mathrm{a}}$ ed. São Paulo: Companhia Editora Nacional. 777p.

LARCHER W. 2000. Ecofisiologia vegetal. São Carlos: RiMa. 531p.

LOPES SJ; BRUM B; SANTOS VJ; MELO EFRQ; SANTOS OS; COUTO MRM. 2007. Área foliar e número de flores de nastúrcio sob duas densidades de plantio. Horticultura Brasileira 25: 159-163.

LORENZI H; SOUZA HM. 2008. Plantas ornamentais no Brasil-arbustivas, herbáceas e trepadeiras. $4^{\mathrm{a}}$. ed., São Paulo: Plantarum. p.296-297.

MAGALHÃES ACN. 1985. Análise quantitativa do crescimento. In: FERRI MG. (coord) Fisiologia vegetal. 2a . ed. São Paulo: EDUSP. v.1, p.333-350.

MARTINS ER; CASTRO DM; CASTELLANI DC; DIAS JE. 1994. Plantas medicinais. Viçosa: UFV. p.96-97.

MARTINEZ HEP. 1997. O uso do cultivo hidropônico de plantas em pesquisa. Viçosa: UFV. 37p. (Cadernos didáticos, 1).

MARTINEZ HEP; BARBOSA JG. 1996. O cultivo de flores sob hidroponia. Viçosa: UFV. 25p. (Boletim de extensão, 38).

MELO EFRQ. 2006. Produção de nastúrcio em cultivo hidropônico com diferentes soluções nutritivas. Santa Maria: UFSM. 49p. (Tese doutorado).

MELO EFRQ; SANTOS OS. 2006. Comportamento de nastúrcio (Tropaeolum majus L.) em hidroponia, Santa Maria, RS. In: CONGRESSO BRASILEIRO DE OLERICULTURA, 46. Resumos... Goiânia: SOB (CD-ROM).

MORAES TC; VIEIRA MC; ZÁRATE NAH; TEIXEIRA IR. 2004. Produção de Tropaeolum majus L. em função de populações de plantas e do uso de cama-de-frango semi decomposta. In: CONGRESSO BRASILEIRO DE OLERICULTURA, 44. Resumos... Campo Grande: SOB (CD-ROM).

RAMOS MBM; MANTOVANELI MCH; VIEIRA MC; ZÁRATE NAH; BARROS EO; SILVA CAA; TEIXEIRA IR. 2003. Produção de flores e de frutos de Tropaeolum majus L. em função de espaçamentos entre plantas e uso de cama-de-aviário. In: CONGRESSO BRASILEIRO DE OLERICULTURA, 43. Resumos... Recife: SOB (CD-ROM).

REIS FC; NOVELINO JO; VIEIRA MC; MARCHETTI ME; RODRIGUES 
E. 2006. Componentes de produção da capuchinha influenciados pela fertilização com nitrogênio e fósforo em um Latossolo vermelho distroférrico. In: CONGRESSO BRASILEIRO DE OLERICULTURA, 46. Resumos... Goiânia: SOB (CD-ROM).

RUSNAK J. 1999. Edible flowers, fresh herbs, baby vegetables: still room for growth.
Produce Business 15: 33-37.

SANGALLI A; VIEIRA MC; ZÁRATE NAH. 2004. Resíduos orgânicos e nitrogênio na produção de biomassa da capuchinha (Tropaeolum majus L.) Jewel. Ciênc. agrotec. 28: 831-839.

SANTOS OS. 2010. Soluções nutritivas. In: SANTOS OS. (ed). Hidroponia. Santa Maria:
UFSM/Colégio Politécnico. p.80-99.

SANTOS OS; NOVELLA M; MEDEIROS S; DURANTE E; SINACHAK, S; FABBIRN E; RIFFEL C; FAGAN E. 2004. Produção de agrião hidropônico. Santa Maria: UFSM. 8p. (Informativo técnico, 05)

TEIXEIRA NT. 1996. Hidroponia: uma alternativa para pequenas propriedades. Guaíba: Agropecuária. 86p. 